\title{
Emotional Intelligence in Leadership
}

\author{
Dr. Ing. Anna Rostomyan ${ }^{1 *}$, Dr. Armen Rostomyan ${ }^{2}$ \\ 1 "PORSCHE” AG ARM Recruiter, University of Fribourg, Switzerland, Independent Research Group Member \\ 2"Autohaus” LLC, After Sales Director
}

*Corresponding Author: Dr. Ing. Anna Rostomyan, "PORSCHE" AG ARM Recruiter, University of Fribourg, Switzerland, Independent Research Group Member

\begin{abstract}
Nowadays, in today's globalized world there is an urgent need of good and effectively proficient leaders, more than ever before. Any employer in any field has come to the understanding that human resources are the most important capital and the main potential in the blossoming and success of any business, and hence, should be given their appropriate place, sufficient significance and proper value.

If we look at the evolution of business administration, we can pinpoint that nowadays we have reached a state where we need to understand everything on the social 'neuro-' level. The present paper looks at leadership at the level 'neuro' where we unveil how some self-aware leaders lead their own and other peoples' brains using a strong arsenal of Emotional Intelligence (Goleman 1995).

To better understand the concept of Neuroleadership, we need to first understand the leader, its human self, its inner world, emotions, feelings, belief, desires (Bass 1985), that truly inspire him or her to commit himself/herself to attaining great results in this or that field of enterprise. Besides, we address today's challenges that most leaders in organizations are faced with: how to choose the right staff both with the correct IQ and right personal and social skills that altogether build the overall $E Q$ of the person.
\end{abstract}

Keywords: Emotions, Ration, Emotional Intelligence (EQ), Leadership, Neuroleadership.

\section{INTRODUCTION}

According to the definition by M. Chambers the term and phenomenon of "Leadership" has been perceptively described as "a contagious process of social influence in which a definite person can enlist the aid and support of others in the accomplishment of a common task or a mutual desired goal". In other words it is the actual guidance of cooperation for a main mutually beneficial goal.

The term "Neuroleadership", which comes to suggest that for being able to successfully lead others we have to control the neuro-psychological level of all the interactants involved, that is to say that leaders should be aware of both their feelings and the feelings of their collaborators.

This term refers to the application of findings from Neuroscience to the field of Leadership. It was first coined by David Rock, a leadership consultant, in the US publication Strategy+Business in 2006 (Lafferty \& Alford 2010). Neuroleadership is the study of leadership through the lens of neuroscience and explores central elements of leadership, including: (a) self-awareness (b) awareness of others, (c) insight, (d) decision making, and (e) influencing.

As a new field of study, the concept of Neuroleadership brings the knowledge of neuroscientific research into the areas of leadership development, education training and management, consulting and coaching tutorials. Neuroleadership largely makes use of Emotional Intelligence which is the ability to assess, identify and control emotions, both in ourselves and in other people.

Once Eleonor Roosevelt, the American politician, diplomat and back then first lady said: "To handle yourself, use your head, to handle others, use your heart". Or else, how the French novelist Antoine de Saint-Exupéry precisely mentions in "The Little Prince": "It is only with the heart that one can see rightly; what is essential is invisible to the eye."

Thus, connecting with the hearts of teammates creates the cutting edge of people-driven advantage. So, in case businessmen and managers manage to combine their hearts and minds, they will surely 
stand a better chance of succeeding. In case they lead their subordinates with both EQ and IQ every business will eventually flourish.

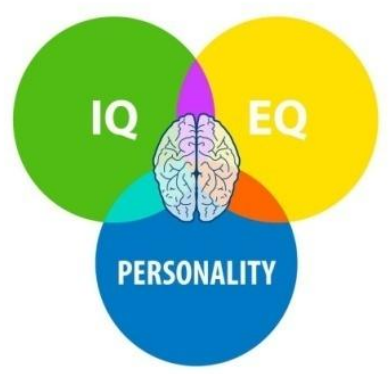

Chart1: The Interrelation of the concepts $I Q, E Q \&$ Personality

For most people, Emotional Intelligence (EQ) is more important than one's intelligence (IQ) in attaining success in their lives and careers. "Your EQ is the level of your ability to understand other people, what motivates them and how to work cooperatively with them", says Howard Gardner, the influential Harvard theorist. We think that we all should find the golden middle of the balance between IQ and EQ.

Our emotional state varies along the day depending on what happens to us and on the stimuli that we perceive. The experience and expression of emotions comprise a routine, yet extraordinarily complex and influential facet of the human experience, particularly in the realm of interpersonal communication (Rostomyan 2012).

In the book "Fundamental Neuroscience" the authors explain that because of the changes that occur around an individual, each sensory system has the task of providing a constantly updated representation of the external world. In doing so, the descending mechanisms alter ascending inputs in ways that optimize perception how we regard our surrounding world (Squire, Berg, Bloom et al. 2008).

\section{LITERATURE REVIEW}

\subsection{The Role of Emotions in our Lives}

Emotions are factually physiological and psychological responses that influence, perception, learning, and performance. The area of emotion is complicated by the lack of general agreement on a basic definition of the nature of the concept. For example, some scientists take the position that emotion is an entirely different process from motivation (Murray 1964).

Furthermore, we firmly believe that sometimes emotions can be guided by rational mind due to background knowledge - cultural, ethnic, familial, religious, social, historical information stored in one's memory. Therefore, it should be stressed that a person's previous emotional experience can also greatly determine the present emotional state which, accordingly, may become verbalized in the process of communication (Paronyan \& Rostomyan 2011).

R. Frager and J. Fadiman (2006) explain that according to William James, the founder of Neuropsychology, there are at least five different kinds and layers of our own self, which are very essential when dealing with people, since we cannot lead our teams, in case we are not well aware of our inner crafts, as well as strong and weak sides.

The five-folded depiction of our "self" is briefly presented below:

Our "Self": this is the inner feeling of our being every morning we wake up. All the psychological processes are rooted in this perspective of the "neuro-self". This layer of the "self" is discreetly and continuously and incessantly present in all the other layers of our "I" (Knowles \& Sibicky 1990).

The Biological "Self": this is our biological, physical self which is embodied in our heritage of our ancestors, our DNA. The construction, outer figure of our "self" and all the interrelated psychological processes form our biological "self". This unique "ship" carries us till we pass away from this real world. Our biological "I" can be viewed as the multiple composition of our real "I". 
The Real (Material) "Self": this is the layer which encompasses all the objects which the individual identifies as composites of his/her own self, such as mother, father, sister, brother, husband, wife, children, grandparents, relatives, friends, etc. This means that the house you live in, your family and friends all they emerge into your "real self". The more a person identifies another person as identical with him/her, the better they become part of his/her "self".

The Social "Self": we happily or indulgently or not so happily get involved in the roles that life and fortune gift us. One and the same person can have a number of different roles, thus having diverse social "selves". These "selves" may be consistent or may change and be variable depending on the situational context. According to W. James to act appropriately means to find the according social "self" which corresponds to the needs of the aroused situation. (Frager \& Fadiman 2006, p. 21-26)

The Spiritual "Self": this is the subjective inner essence of the personality. This element is co-existent and prevalent in all other layers of our "selves". James very much wanted to find why we consider ourselves as something prior to the sum of all the other existing things surrounding us, thus as a result of his investigations he found out that it is some kind of "spiritual power".

William James (James 1890) was not fully assured of the definite existence of the "soul" of human beings, but he supposed that the individual identification is not all. He explained from his own experience that as a constant continuum of cosmic consciousness from which our individuality is separated by inconsistent layers where our other selves are kept as a boundless sea or reservoir (Murphy \& Ballou 1960: 324).

When speaking about the "spiritual self", it is notable that Pope Francis has declared the Armenian monk St. Gregory of Narek (950-1003 A.D.) century mystic and poet revered in particular by Armenian Catholics, a doctor of the church and Master of the universe. The title of doctor of the church is reserved for people whose writings have greatly served for the benefit of the universal church.

When we code and decode information, we are simultaneously performing a number of activities connected with 3 main aspects which are presented in the Chart 2 drawn below:

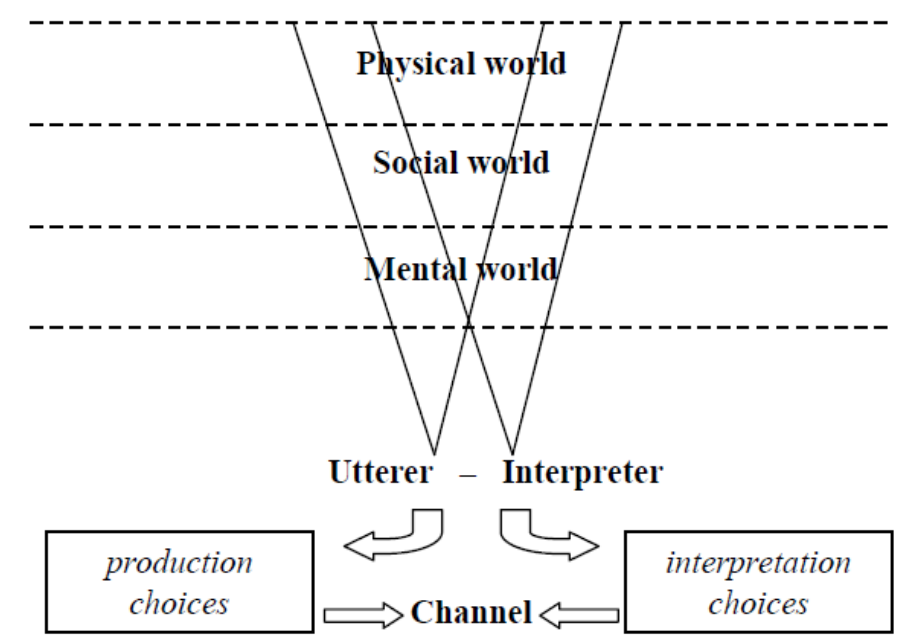

(Linguistic context)

Chart2: Contextual correlates of adaptability (Verschueren 1999: 76)

As we see, the communicative context involves several ingredients which are: the mental world, the social world and the physical world. First of all, the information is being processed in the brain of the speaker. In fact, humans do not exist apart from each other, in other words we are not devoid of any social connection, and thus our social world is always participating in the process of communication. Here, culture is of paramount importance since a lot of factors connected with the social world are governed by means of a number of culturally bound rules and conventions (Verschueren 1999: 91).

It is of utmost importance to note that we firmly believe human feelings and emotions to have an impact on our mental world and are very often being manifested in speech when we do not manage to suppress a particular emotion or when we want to have an emotive impact on the interlocutors, as mentioned in our earlier discussions, we display this or that emotion in an exaggerated manner. 
Last but not least, our physical world is of utmost importance as well, since the relativity of temporal and spatial reference is primarily a function of positioning of language users in the world. As known, a lot of choice-making is dependent in these phenomena. In a number of cases the interlocutors' position in the physical world is important in determining a lot of linguistic choices and their meanings. Notably, we distinguish between utterer and interpreter since the contextual aspects of the physical, social, and mental worlds do not usually start to play an eminent role in language use unless they have in this way or another been activated by the language users' cognitive processes. It is also very important to note that the elements of all the aforementioned worlds may overlap.

Finally, Chart 2 also indicates that the utterer makes production choices, whereas the interpreter makes interpretation choices depending on diverse extralinguistic factors.

We may generalize that all these aspects form a kind of background information for the interlocutors which is a very important factor in the process of interpretation. Here, the background mutual emotions between the interlocutors are very crucial the formation of which is certainly connected with their mental world, as we do believe that emotional memory has a great impact in the decoding process (Rostomyan 2012; Verschueren 1999).

\subsection{Communicative Emotional Influence in Leading People}

It is no longer a secret that a good leader should also be a proficient communicator who is able to deal with speech conflict situations, draw the communication in his/her desired direction and to attain the desirable results, simultaneously having an emotive impact on the interactants. According to the model of Dr. Thorsten Quandt, a Professor of Communication Studies at the University of Münster, the human societal communication system has evolved during the years. Thus, for instance the early stage of communication processes, according to the author, looks like this as depicted in Diagram 1 where we have one-to-one message transmission and receipt.

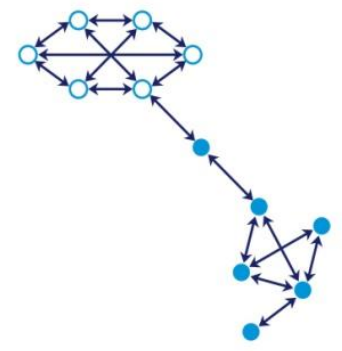

Diagram1: Early Stage Communication (Quandt 2012, p. 11)2

Here we have simple societies where people mainly interact by means of face-to-face communication; two way communications: on the one hand the encoder (speaker), on the other hand the decoder (interpreter), it's a 1-to-1 communication where the main interactants constantly change roles. The communication is direct; it's interactive, synchronous and reactive where the main actors at hand have equal nods.

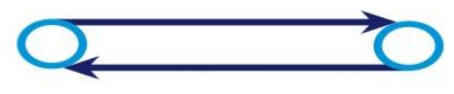

Diagram2: One to one communication process

In the next phase we have modern societies where there is the problem of complexity of reach and distance. We can talk to people within far distances by means of technological appliances. For the information digestion we have the selection capacity of observing and reporting which can be described as qualitative and quantitative selections. 


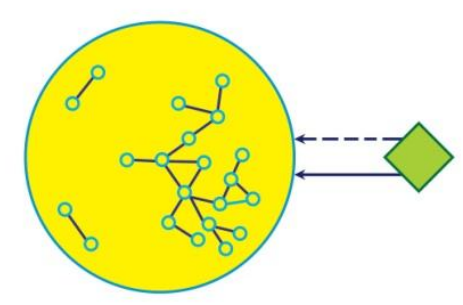

Diagram3: Modern societies (Quandt 2012, p. 12)

In this case the communication processes are selective. Communication, hence, can be described as one-way, 1-to many; it's indirect, non-reactive, unequal nods (i.e. mass audience + organizations).

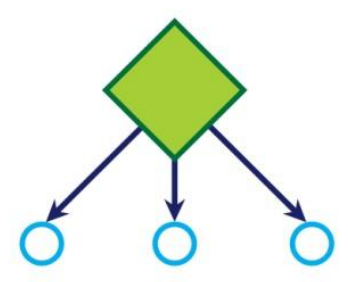

Diagram4: Modern communication processes

Yet, it should by all means be mentioned that in the 21 st century digitalized community the societies have become really hyper-complex. Media communications are all over which include millions of interactants. Nonetheless, there is a steady dilemma of misinterpretation because of complex societies as illustrated in the diagram depicted below:

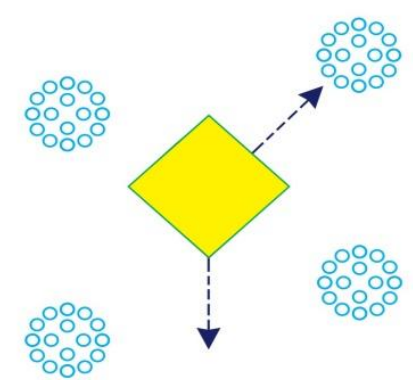

Diagram5: Hypercomplex societies (Quandt 2012, p. 12)

Here the communication processes are very similar to the former one of modern societies with the addition of problem adaptation. In this case we have dynamics of communication due to the network system, detachment while communication and not one-to-one way of communicating, specialization of communicated topic, individualization of the decoders, sometimes disintegration because of wide social networks.

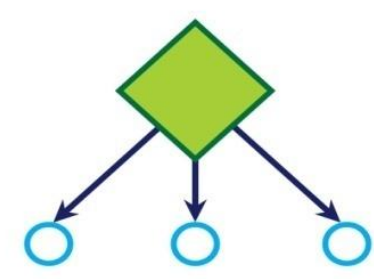

Diagram6: Modern hypercomplex communication direction 
In summary, it should be noted that emotions are very prominent in leadership. Factually, the analysis of the linguistic mechanisms of verbalization of emotions in the process of interpersonal communication, which has become quite urgent today, should be realized on the basis of cognitive evaluation of emotivity.

\section{CaSe Study In Financial Organizations}

To reveal the emotional intelligence awareness amongst the baking people and the nature of leaders and emotions in the social field of finance, we have interviewed 40 people aging from 20 to 60 at one of Armenian big financial organizations. The results are illustrated in the chart:

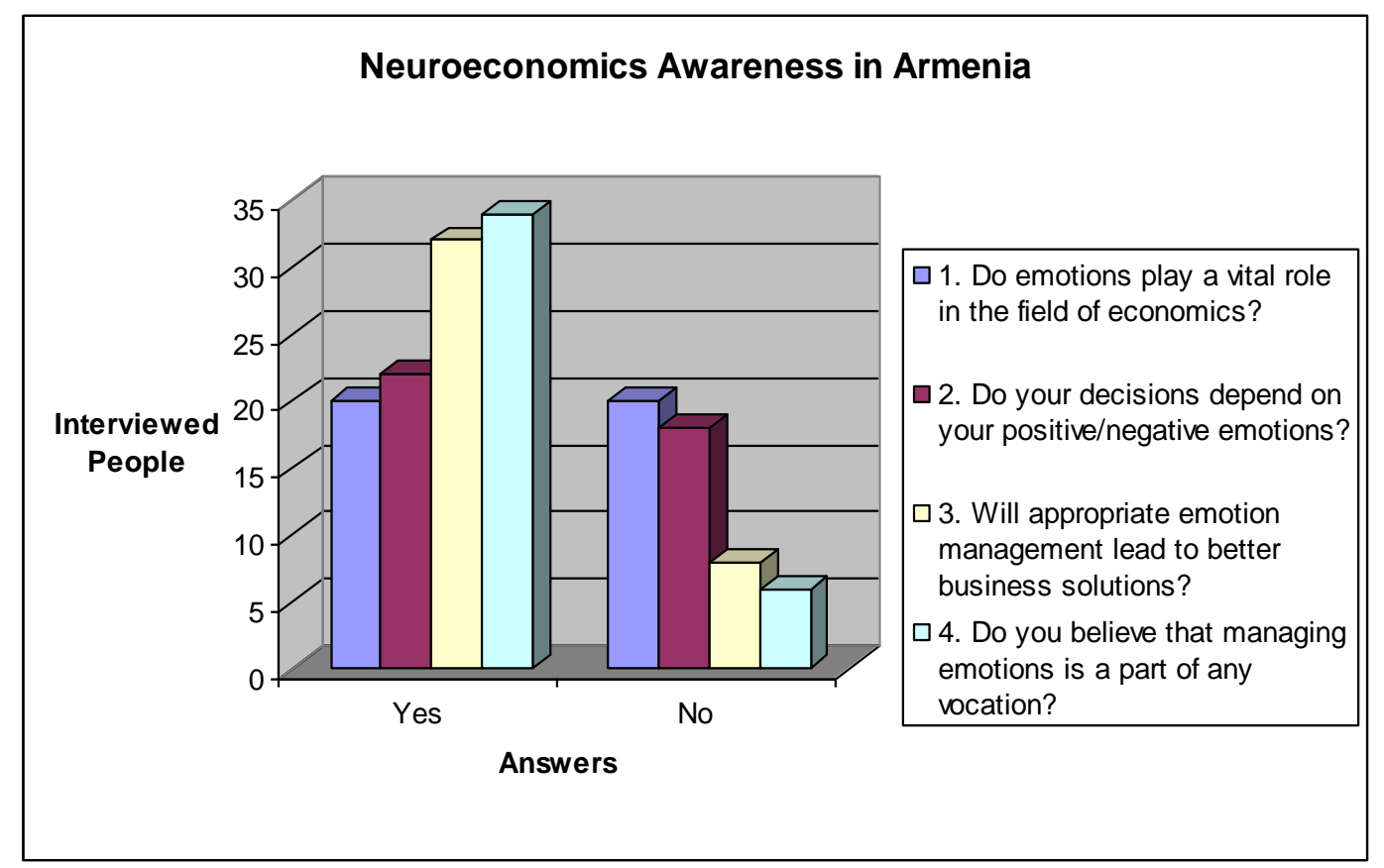

Chart3: The awareness of e-banking in Neuroeconomics in Armenia

The answers come to prove that though theoretically people in financial organizations in Armenia do realize the ultimate importance of emotional intelligence and the urgency of managing emotions at work for better financial outputs, they still doubt whether or not emotions and economics are interlinked and intertwined, as the answers have been divided to 50/50. This basically suggests that emotion management is apparently present in the Armenian financial organizations.

As for the question whether leadership is an inborn quality or an acquired skill, the answers were very close still leaving some ground for further doubt. Yet, if we take the stance that leadership can be a trained skill, beyond any doubt we may claim that here the role of acquired emotional intelligence is of paramount importance, since by means of managing our own emotions and the emotions of the others we stand a better chance of leading them towards our desired direction and the sought goal.

From the above, it follows that the term Neuroleadership is quite actual today, and that by means of teaching our managerial stuff emotion management skills and raising their emotional intelligence, we will create better and more skillful leaders. In this perspective, quoting the words of the well-known American football player, coach, and executive Vincent Thomas "Vince" Lombardi: "Leaders aren't born they are made. And they are made just like anything else, through hard work."

\section{CONCLusion}

Summing up, emotions constitute an unbelievably very large part in our lives. Consciously or subconsciously, we are almost always experiencing some sort of emotion or feeling which guides us throughout the whole day or even a week and which may greatly influence our behaviour and subsequent decisions. Neuroleadership focuses on applying neuroscience to leadership development, management training, as well as other coaching activities for building better human resources with a series of strategically designed seminars and tutorials. The concept of Emotional Intelligence, here, is seemingly tightly linked with the field of Neuroleadership that comes to prove by means of having a trained stuff of emotionally skilled leaders any financial organization is sure to flourish and prosper. 


\section{REFERENCES}

[1] Bass, B.M. (1985). Leadership and Performance beyond Expectations. New York: Free Press.

[2] Carnegie, D. (1982). How to Win Friends and Influence People. New York, London, Toronto, Sydney: Pocket Books.

[3] Frager, R., \& Fadiman, J. (2006). "Personality and Personal Growth" Saint-Petersbourg: Prime-Evroznak

[4] Freese, J. H. (1926). Aristotle. Cambridge and London: Harvard University Press.

[5] Goldie, P. (2000). The Emotions: A Philosophical Exploration. New York, Oxford: Oxford University Press.

[6] Goleman, D. (1995). Emotional Intelligence. New York, Toronto, London, Sydney, Auckland: Bantam Books.

[7] Graves, R.H. (1934). The Triumph of an Idea: The Story of Henry Ford. New York: Country Life Press.

[8] Grice, H.P. (1969). Utterer's Meaning and Intentions. Philosophical Review, New York: Academic Press.

[9] Grice, H.P. (1975). Logic and Conversation. In P. Cole \& J. Morgan (Eds). Syntax and Semantics, Vol. 3, New York: Academic Press.

[10] Griffiths, P.E. (1997) What Emotions Really Are. London, Chicago: Chicago University Press.

[11] Hochschild, A.R. (1983). The Managed Heart: Commercialization of Human Feeling. Berkeley: University of California Press.

[12] Hsieh, T. (2010). Delivering Happiness: A Path to Profits, Passion, and Purpose. New York, Boston: Business plus Press.

[13] James, W. (1890). The Principles of Psychology. Classics in the History of Psychology. An internet resource developed by Christopher D. Green of York University. Toronto, Ontario.

[14] Kenning, P., Plassmann, H. (2005). NeuroEconomics: an Overview from an Economic Perspective. Brain Res Bull, 67, 343-354.

[15] Knowles, E., \& Sibicky, M. (1990). Continuity and Diversity in the Stream of Selves: Metaphorical Resolutions of William Jame's One-in-many-selves Paradox. Personality and Social Psychology Bulletin, 76(4), 676-687.

[16] Lafferty, Christina L.; Alford, Kenneth L. (2010). NeuroLeadership: sustaining research relevance into the 21st century. SAM Advanced Management Journal.

[17] Lakoff, D. \& Lu, F. (1989). Transpersonal Psychology Research Review. Topic: Computerized databases, specialized collections. Journal of Transpersonal Psychology, 21(2), 211-223.

[18] Lyons, W. (1980). Emotion. Cambridge Studies in Philosophy. Cambridge: Cambridge University Press.

[19] Murphy, G. \& Ballou, R. (Eds.) (1960). William James on Psychical research. New York: Viking Press.

[20] Paronyan, Sh, Rostomyan, A. (2011). On the Interrelation between Cognitive and Emotional Minds in Speech. Armenian Folia Anglistika, International Journal of English Studies, № 1-2(8), Yerevan: Lusakn Publishers.

[21] Quandt, T. (2012). What's Lest of Trust in a Network Society? An Evolutionary Model and Critical Discussion of Trust and Societal Communication. In P. Golding, H. Sousa, L. van Zoonen (Eds.) European Journal of Communication, 27 (1). UK: Sage Publications Ltd.

[22] Rock, D. (2013). Handbook of NeuroLeadership. New York: CreateSpace Independent Publishing Platform.

[23] Rock, D. (2007). Quiet Leadership: Six Steps to Transforming Performance at Work. New York: Harper Business

[24] Rostomyan, A. (2012). The Vitality of Emotional Background Knowledge in Court, Polemos, 6(2), (281292), Boston, Berlin: De Grutyer.

[25] Rostomyan, A. (2013a). Management Techniques of Emotions in Communicative Conflict Reduction, in part 3: Communication and Management, Communication: Breakdowns and Breakthroughs, Probing the Boundaries, eds. Anabel Ternès, Inter-disciplinary Press, (141-151). UK: Oxford.

[26] Rostomyan, A. (2013b). A Linguo-cognitive Analysis of Verbal and Non-verbal Displays of Emotions (on the material of English), dissertation, summary, 27 pages, Yerevan, Armenia.

[27] Squire, L.; \& Berg, D.; Bloom, F.; du Lac, S., Ghosh, A.; Spitzer, N. (2008) Fundamental Neuroscience. Amsterdam: Academic Press, Elsevier.

[28] Verschueren, J. (1999). Understanding Pragmatics. Amsterdam: Hodder Education Publishers. 
[29] Williams, M. (2007). Building Genuine Trust through Interpersonal Emotion Management: A Threat Regulation Model of Trust and Collaboration across Boundaries. The Academy of Management Review Archive, 2(2), 595-621.

[30] Yule, G. (1996). Pragmalinguistics, Oxford Introductions to Language Study, series editor H. G. Widdowson. Oxford, New York: Oxford University Press.

\section{AUTHORS' BIOGRAPHY}

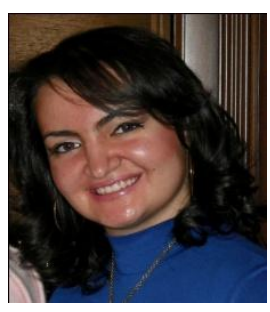

Name: Dr. Anna Rostomyan

Education: PhD in Philology and Philosophy, Faculty of Romance and Germanic Philology, English Philology Department, Yerevan State University.

Bachelor Thesis: "Classicism and Emotions in Late Medieval England"

Master's Thesis: "Means of Expressing Emotive Emphasis in Conversational English". Doctor of Philosophy in Philology

Dissertation Title: “A Linguo-cognitive Analysis of Verbal and Non-verbal Display of Emotions".

Main Research Interests: Psycholinguistics, Pragmatics, Cognitive Linguistics, Forensics.

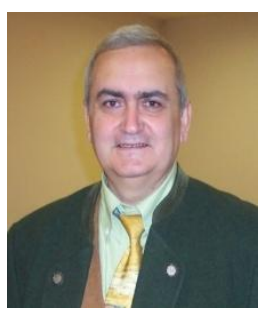

Name: Dr. Armen Rostomyan

Education: PhD in Physics, Faculty of Physics, Solid State Physics Department, Yerevan State University. Doctor of Physics,

Dissertation Title: "Application of X-Ray Resonators in Gyroscopy".

Main Research Interests: Solid State Physics, X-rays, Resonators, Monochromators, Automotive After-Sales, Spare Parts.

Citation: Dr. Ing. Anna Rostomyan, Dr. Armen Rostomyan. "Emotional Intelligence in Leadership" International Journal of Managerial Studies and Research (IJMSR), vol 6, no. 8, 2018, pp. 34-41. doi:http://dx.doi.org/10.20431/2349-0349.0608004.

Copyright: () 2018 Authors. This is an open-access article distributed under the terms of the Creative Commons Attribution License, which permits unrestricted use, distribution, and reproduction in any medium, provided the original author and source are credited. 